\title{
Risk Factors for Gastrointestinal Symptoms post Enteral Nutrition Initiation via a Gastrostomy Tube
}

\author{
Yusaku Kajihara \\ Department of Gastroenterology, Fuyoukai Murakami Hospital, Japan
}

\section{Corresponding author:}

Yusaku Kajihara. 3-3-14 Hamada, Aomori 030-0843 Japan. Phone: +81-17-729-8888; Facsimile: +81-17-7298887.E-mail:y_kaji2012@yahoo.co.jp

\begin{abstract}
Background: Percutaneous endoscopic gastrostomy (PEG) facilitates long-term enteral nutrition. However, parenteral nutrition prior to PEG tube placement can cause impaired gastrointestinal function. Additionally, upon initiation of enteral feeding via a PEG tube, some patients suffer from gastrointestinal symptoms (e.g., vomiting, diarrhea), which reduce their quality of life and increase the nursing workload.

Method: This retrospective study included 155 patients upon whom the author performed $P E G$ as the attending physician. Enteral nutrition was started through the PEG tube on the third day after its placement. The following characteristics were analyzed: age, gender, indications for PEG, preoperative enteral nutrition, administered liquid nutrients, daily dosage of nutrients, serum albumin levels, serum alanine aminotransferase levels, serum creatinine levels, serum hemoglobin levels, and vomiting or diarrhea within seven days after the initiation of PEG feeding. A logistic regression model was used to identify the risk factors contributing to gastrointestinal symptoms, and three variables were sequentially introduced into the model-preoperative non-enteral nutrition, hypoalbuminemia, and administration of non-elemental diets.
\end{abstract}

Results: Vomiting and diarrhea occurred in 10 and 15 patients, respectively. There were significant differences in administered nutrients and serum albumin levels between patients with and without gastrointestinal symptoms. Multivariate analysis revealed that the adjusted odds ratios for administration of non-elemental diets and serum albumin level $\leq 3.2 \mathrm{~g} / \mathrm{dL}$ were 8.05 (95\% confidence interval (CI): 2.66-24.4; $p<0.001)$ and 3.81 (95\% CI: $1.33-10.9 ; p<0.05)$, respectively.

Conclusion: The administration of non-elemental diets and a serum albumin level $\leq 3.2 \mathrm{~g} / \mathrm{dL}$ were significant risk factors.

Keywords: albumin, diarrhea, elemental diet, percutaneous endoscopic gastrostomy, vomiting

\begin{abstract}
ABSTRAK
Latar belakang: Gastrostomi endoskopik perkutan (GEP) membantu pemberian nutrisi enteral jangka panjang. Walaupun demikian, pemberian nutrisi parenteral sebelum penggantian pipa GEP dapat menyebabkan gangguan fungsi gastrointestinal. Selain itu, setelah inisiasi pemberian makanan enteral melalui selang GEP, beberapa pasien dapat mengalami gejala-gejala gastrointestinal (misalnya, muntah, diare), yang dapat menurunkan kualitas hidup mereka dan meningkatkan beban perawatan.

Metode: Studi retrospektif ini mengikutsertakan 155 pasien yang menjalani prosedur GEP di bawah pengawasan penulis sebagai dokter yang merawat. Nutrisi enteral mulai diberikan melalui pipa GEP pada hari ketiga setelah pipa diganti. Beberapa karakteristikyang dianalisis dalam studi ini adalah sebagai berikut: usia, jenis kelamin, indikasi GEP, nutrisi enteral pre-operatif, nutrisi cair yang diberikan, dosis nutrisi harian, kadar albumin serum, kadar alanine aminotransferase serum, kadar kreatinin serum, kadar hemoglobin serum, dan muntah atau diare dalam 7 hari setelah pemberian makan melalui GEP. Model regresi logistik digunakan
\end{abstract}


untuk mengidentifikasi faktor risiko yang berkontribusi terhadap gejala-gejala gastrointestinal, dan tiga variabel secara berurutan dimasukkan ke dalam model - nutrisi non-enteral pre-operasi, hipoalbuminemia, dan pemberian diet non-elemental.

Hasil: Muntah dan diare masing-masing terjadi pada 10 dan 15 pasien. Terdapat perbedaan yang bermakna antara nutrisi yang diberikan dan kadar albumin serum pada pasien yang mengalami dan tidak mengalami gejala-gejala gastrointestinal. Analisis multivariat menunjukkan bahwa odds ratio yang disesuaikan untuk pemberian diet non-elemental dan kadar albumin serum $\leq 3.2 \mathrm{~g} / \mathrm{dL}$ adalah 8.05 (Interval Kepercayaan (IK) 95\%: 2.66-24.4; $p<0.001$ ) dan 3.81 (95\% CI: 1.33-10.9; $p<0.05$ ), secara berturut-turut.

Simpulan: Pemberian diet non-elemental dan kadar albumin serum $\leq 3.2 \mathrm{~g} / \mathrm{dL}$ merupakan faktor risiko yang bermakna.

Kata kunci: albumin, diare, diet elemental, gastrostomi endoskopik perkutan, muntah

\section{INTRODUCTION}

"If the gut works, use it." The key to achieving successful nutrition is gastrointestinal tract feeding access. The purpose of enteral nutrition is to sustain mucosal barrier function, along with intestinal immune response and normal flora, by maintaining gastrointestinal mucosal integrity. ${ }^{1}$ Percutaneous endoscopic gastrostomy (PEG) facilitates long-term enteral nutrition. ${ }^{2}$

The American Society for Parenteral and Enteral Nutrition and the Japanese Society for Parenteral and Enteral Nutrition have recommended the use of gastrostomy tubes for patients whose nutritional intake is likely to be qualitatively or quantitatively inadequate for a period exceeding four weeks. ${ }^{3}$ However, parenteral nutrition prior to PEG tube placement can cause impaired gastrointestinal function. ${ }^{4}$ Additionally, upon initiation of enteral feeding via a PEG tube, some patients suffer from gastrointestinal symptoms (e.g., vomiting, diarrhea), which reduce their quality of life and increase the nursing workload. Furthermore, aspiration pneumonia and dehydration due to diarrhea are life-threatening complications of enteral nutrition.

The aim of this study was to identify the risk factors contributing to gastrointestinal symptoms when liquid nutrients, which are frequently used in clinical practice, were administered after PEG tube placement.

\section{METHOD}

This retrospective study included 185 patients upon whom the author performed PEG as the attending physician from August 1, 2011 to March 31, 2020. Excluded from the study were: 24 patients receiving enteral nutrition with semi-solid medical foods; five patients having a previous history of pyloruspreserving gastrectomy or esophagectomy with gastric tube reconstruction; and one patient with no enteral feeding after PEG tube placement. One hundred fiftyfive patients were investigated.

Before PEG tube insertion, there were no instances of fever, hypoxemia, vomiting, or diarrhea among the patients. All patients received $1 \mathrm{~g}$ ceftazidime intravenously twice daily for three days as antibiotic prophylaxis, and a 24-Fr PEG tube was placed using the modified introducer technique without complications. Enteral nutrition through the PEG tube was started on the third day after its placement. A gravity-controlled method was used to administer liquid nutrients (600$1,200 \mathrm{kcal} /$ day) at a speed of $250-400 \mathrm{~mL} / \mathrm{h}$.

Patient data extracted from medical records included the following: age, gender, indications for PEG, preoperative enteral nutrition, administered liquid nutrients, daily dosage of nutrients, serum albumin levels, serum alanine aminotransferase levels, serum creatinine levels, serum hemoglobin levels, and gastrointestinal symptoms (vomiting or diarrhea) within seven days after the initiation of enteral feeding via a PEG tube. Diarrhea was defined as liquid or loose stool at least three times a day, and stool sample-based tests confirmed non-infectious causes. A logistic regression model was used for identifying the risk factors that contributed to gastrointestinal symptoms, and three variables were sequentially introduced into the modelpreoperative non-enteral nutrition, serum albumin level $\leq 3.2 \mathrm{~g} / \mathrm{dL}$, and administration of non-elemental diets. Youden index (sensitivity $=59.2 \%$; specificity $=72.0 \%$ ) was used to obtain the abovementioned cut-off value for serum albumin level upon the onset of gastrointestinal symptoms in the receiver operating characteristic curve analysis (area under the curve $=0.666 ; 95 \%$ confidence interval (CI): 0.557-0.775).

The present study was approved by the institutional ethics committee. Informed consent was obtained from 
the patients or their families. Statistical analysis was performed with EZR (Easy R, Version 1.37, Saitama, Japan), and $p$ values of less than 0.05 were considered to be statistically significant. ${ }^{5}$ The author used the twosided Mann-Whitney U test or the Fisher's exact test for the differences between the two groups.

\section{RESULTS}

Patients' backgrounds are summarized in Table 1, and administered liquid nutrients are shown in Table 2. The median age of patients was 81 years, and $54.2 \%$ of patients $(84 / 155)$ were females. Approximately three- fourths of indications for PEG were dementia $(40.0 \%$, $62 / 155)$ and cerebrovascular disease $(36.8 \%, 57 / 155)$. Gastrointestinal symptoms occurred in $25(16.1 \%)$ patients; vomiting and diarrhea occurred in $10(6.5 \%)$ and $15(9.7 \%)$ patients, respectively. The differences were significant in administered nutrients and serum albumin levels between patients with and without gastrointestinal symptoms. Multivariate analysis revealed that the adjusted odds ratios for administration of non-elemental diets and serum albumin level $\leq 3.2 \mathrm{~g}$ / dL were 8.05 (95\% CI: 2.66-24.4; $p<0.001)$ and 3.81 (95\% CI: $1.33-10.9 ; p<0.05$ ), respectively (Table 3 ).

Table 1 Patients' backgrounds $(n=155)$

\begin{tabular}{|c|c|c|c|c|}
\hline & \multirow{2}{*}{ Overall } & \multicolumn{2}{|c|}{ 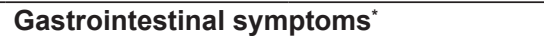 } & \multirow[b]{2}{*}{$-p$} \\
\hline & & Positive $(n=25)$ & Negative $(n=130)$ & \\
\hline Age $(y)$, median & 81 & 81 & 81 & 0.554 \\
\hline Female, n (\%) & $84(54.2)$ & $14(56.0)$ & $70(53.8)$ & 1 \\
\hline Indications for PEG, n (\%) & & & & 0.0851 \\
\hline Dementia & $62(40.0)$ & $10(40.0)$ & $52(40.0)$ & \\
\hline CVD & $57(36.8)$ & $6(24.0)$ & $51(39.2)$ & \\
\hline Sarcopenia & $24(15.5)$ & $6(24.0)$ & $18(13.8)$ & \\
\hline Malignancy & $5(3.2)$ & $3(12.0)$ & $2(1.5)$ & \\
\hline Parkinson's disease & $4(2.6)$ & 0 & $4(3.1)$ & \\
\hline Schizophrenia & $3(1.9)$ & 0 & $3(2.3)$ & \\
\hline Preoperative enteral nutrition, $\mathrm{n}(\%)$ & $101(65.2)$ & $12(48.0)$ & $89(68.5)$ & 0.0662 \\
\hline Administered liquid nutrients, $n(\%)$ & & & & 0.00253 \\
\hline Elemental diets & $84(54.2)$ & $6(24.0)$ & $78(60.0)$ & \\
\hline Polymeric formulae & $57(36.8)$ & $15(60.0)$ & $42(32.3)$ & \\
\hline Oligomeric formulae & $14(9.0)$ & $4(16.0)$ & $10(7.7)$ & \\
\hline Daily dosage of nutrients $(\mathrm{mL})$, median & 900 & 900 & 900 & 0.580 \\
\hline Serum albumin level (g/dL), median & 3.3 & 3.0 & 3.3 & 0.00855 \\
\hline Serum alanine aminotransferase level (IU/L), median & 18 & 16 & 18 & 0.969 \\
\hline Serum creatinine level $(\mathrm{mg} / \mathrm{dL})$, median & 0.56 & 0.57 & 0.56 & 0.461 \\
\hline Serum hemoglobin level $(\mathrm{g} / \mathrm{dL})$, median & 11.8 & 11.1 & 11.9 & 0.160 \\
\hline
\end{tabular}

*: vomiting or diarrhea within seven days after the initiation of enteral feeding via a gastrostomy tube, CVD: cerebrovascular diseases (cerebral infarction, cerebral hemorrhage, subarachnoidal hemorrhage, or subdural hemorrhage), PEG: percutaneous endoscopic gastrostomy.

Table 2. Administered liquid nutrients after PEG tube placement

\begin{tabular}{|c|c|c|}
\hline & $\mathrm{kcal} / \mathrm{mL}$ & $\mathbf{n}$ \\
\hline \multicolumn{3}{|l|}{ Elemental diets $(n=84)$} \\
\hline ELENTAL ${ }^{\circledR} ;$ EA Pharma, Tokyo, Japan & 1.0 & 84 \\
\hline \multicolumn{3}{|l|}{ Oligomeric formulae $(n=14)$} \\
\hline Twinline-NF Liquid for Enteral Use ${ }^{\circledR}$; Otsuka Pharmaceutical, Tokyo, Japan & 1.0 & 14 \\
\hline \multicolumn{3}{|l|}{ Polymeric formulae $(n=57)$} \\
\hline L-8 ${ }^{\circledR}$; Asahi Kasei Pharma, Tokyo, Japan & 1.0 & 18 \\
\hline ENSURE H ${ }^{\circledast}$; Abbott Japan, Tokyo, Japan & 1.5 & 13 \\
\hline RACOL-NF Liquid for Enteral Use ${ }^{\oplus}$; Otsuka Pharmaceutical, Tokyo, Japan & 1.0 & 11 \\
\hline E-7 ${ }^{\circledast}$; Clinico, Tokyo, Japan & 1.0 & 8 \\
\hline Renalen LP®; Meiji, Tokyo, Japan & 1.6 & 2 \\
\hline DIMVest $^{\circledR} ;$ Ajinomoto Pharmaceutical, Tokyo, Japan & 1.0 & 2 \\
\hline Medief $^{\circledR} ;$ Nestle, Tokyo, Japan & 1.0 & 1 \\
\hline Glucerna $^{\circledR}$; Abbott Japan, Tokyo, Japan & 1.0 & 1 \\
\hline ISOCAL 2K Neo ${ }^{\circledR}$; Nestle, Tokyo, Japan & 2.0 & 1 \\
\hline
\end{tabular}

PEG: percutaneous endoscopic gastrostomy. 
Table 3. Results of the multivariate analysis for identifying the risk factors contributing to gastrointestinal symptoms when liquid nutrients were administered after PEG tube placement

\begin{tabular}{|c|c|c|c|c|}
\hline Variables & Crude OR (95\% Cl) & $\mathbf{p}$ & Adjusted OR (95\% Cl) & p \\
\hline Preoperative non-enteral nutrition & $2.35(0.988-5.60)$ & 0.0533 & $2.79(0.973-7.98)$ & 0.0563 \\
\hline Serum albumin level $\leq 3.2 \mathrm{~g} / \mathrm{dL}$ & $3.74(1.46-9.57)$ & 0.00602 & $3.81(1.33-10.9)$ & 0.0125 \\
\hline Administration of non-elemental diets & $4.75(1.78-12.7)$ & 0.00188 & $8.05(2.66-24.4)$ & 0.000228 \\
\hline
\end{tabular}

$\mathrm{Cl}$ : confidence interval, OR: odds ratio, PEG: percutaneous endoscopic gastrostomy.

Table 4. Patients with gastrointestinal symptoms leading to death $(n=7)$

\begin{tabular}{|c|c|c|c|c|c|c|c|}
\hline & Patient 1 & Patient 2 & Patient 3 & Patient 4 & Patient 5 & Patient 6 & Patient 7 \\
\hline Administered nutrients & ED & ED & ED & OF & OF & PF & PF \\
\hline Age $(y)$ & 90 & 79 & 75 & 80 & 95 & 69 & 83 \\
\hline Gender & Female & Male & Female & Female & Female & Male & Female \\
\hline Indications for PEG & Sarcopenia & Dementia & Sarcopenia & CVD & CVD & Dementia & Dementia \\
\hline Serum albumin level (g/dL) & 2.7 & 3.0 & 3.1 & 3.5 & 3.0 & 2.6 & 2.7 \\
\hline Preoperative enteral nutrition & No & No & Yes & No & No & No & Yes \\
\hline Gastrointestinal symptoms & Diarrhea & Vomiting & Vomiting & Vomiting & Vomiting & Vomiting & Diarrhea \\
\hline Causes of death & Heart failure & Pneumonia & Pneumonia & $\begin{array}{l}\text { Paralytic } \\
\text { ileus }\end{array}$ & Pneumonia & Pneumonia & Renal failure \\
\hline
\end{tabular}

CVD: cerebrovascular diseases, ED: elemental diet, OF: oligomeric formula, PEG: percutaneous endoscopic gastrostomy, PF: polymeric formula

\section{DISCUSSION}

Elemental diets consist of essential amino acids, glucose, trace elements, and vitamins. Depending on the amino acid composition, elemental diets are easily absorbed and highly digestible. In fact, Horiuchi et al. reported that elemental diets were less likely to induce diarrhea than standard liquid diets in bedridden, gastrostomy-fed patients. ${ }^{6}$ Additionally, their study revealed that elemental diets were related to more rapid gastric emptying and fewer episodes of aspiration than standard liquid diets, most likely due to their low amounts of lipids. ${ }^{6}$ Therefore, the utility of elemental diets is deemed reasonable.

Diarrhea occurs more commonly in tube-fed patients with hypoalbuminemia. ${ }^{7}$ Patients with hypoalbuminemia caused by chronic malnutrition experience diarrhea more often than those with acute malnutrition. ${ }^{8}$ Hypoalbuminemia is associated with gut edema and impaired nutrient absorption. ${ }^{9}$ Early and aggressive nutritional support is needed to prevent hypoalbuminemia whose presence preoperatively may reflect potential malabsorption.

Preoperative enteral nutrition is suggested for maintaining gastrointestinal function; contrary to expectations, preoperative non-enteral nutrition was not a significant risk factor for gastrointestinal symptoms in the present study. Postoperative nonenteral nutrition for only three days may have caused impaired gastrointestinal function. Even when preoperative enteral nutrition has not been performed, patients with a serum albumin level $>3.2 \mathrm{~g} / \mathrm{dL}$ should undergo PEG tube placement and receive postoperative enteral feeding with elemental diets.
In this study, it should be noted that seven patients died from vomiting or diarrhea, and the rate of gastrointestinal symptoms leading to death was $28.0 \%$ (7/25) (Table 4). Aspiration pneumonia $(57.1 \%, 4 / 7)$ was the most common cause of death. Pump-assisted enteral nutrition or post-pyloric feeding can reduce the risk of aspiration pneumonia. ${ }^{10,11}$ However, these methods require pumps and are more difficult to manage than gravity-controlled enteral nutrition. ${ }^{6}$ In addition, post-pyloric tubes easily become obstructed and displaced. ${ }^{6}$ Semi-solid medical foods may reduce the risk of aspiration pneumonia in gastrostomy-fed patients. ${ }^{12,13}$ My department will be conducting further investigation involving more patients receiving semisolid medical foods.

This study had several limitations. First, patients' gastrointestinal motility may have influenced cases of vomiting or diarrhea. Second, the study design was singlecenter and retrospective. A multicenter, randomized study is necessary for the reduction of selection bias.

\section{CONCLUSION}

The administration of non-elemental diets and a serum albumin level $\leq 3.2 \mathrm{~g} / \mathrm{dL}$ were significant risk factors for gastrointestinal symptoms when liquid nutrients were administered after PEG tube placement.

\section{REFERENCES}

1. Marik PE, Zaloga GP. Early enteral nutrition in acutely ill patients: a systematic review. Crit Care Med 2001;29:2264-70.

2. Grant MD, Rudberg MA, Brody JA. Gastrostomy placement and mortality among hospitalized Medicare beneficiaries. JAMA 1998;279:1973-6. 
3. Boullata JI, Carrera AL, Harvey L, Escuro AA, Hudson L, Mays A, et al. ASPEN safe practices for enteral nutrition therapy. JPEN J Parenter Enteral Nutr 2017;41:15-103.

4. Schörghuber M, Fruhwald S. Effects of enteral nutrition on gastrointestinal function in patients who are critically ill. Lancet Gastroenterol Hepatol 2018;3:281-7.

5. Kanda Y. Investigation of the freely available easy-to-use software 'EZR' for medical statistics. Bone Marrow Transplant 2013;48:452-8.

6. Horiuchi A, Nakayama Y, Sakai R, Suzuki M, Kajiyama M, Tanaka N. Elemental diets may reduce the risk of aspiration pneumonia in bedridden gastrostomy-fed patients. Am J Gastroenterol 2013;108:804-10.

7. Heimburger DC, Sockwell DG, Geels WJ. Diarrhea with enteral feeding: prospective reappraisal of putative causes. Nutrition 1994;10:392-6.

8. Hwang TL, Lue MC, Nee YJ, Jan YY, Chen MF. The incidence of diarrhea in patients with hypoalbuminemia due to acute or chronic malnutrition during enteral feeding. Am J Gastroenterol 1994;89:376-8.

9. Mechanick JI. Practical aspects of nutritional support for wound-healing patients. Am J Surg 2004;188:52-6.

10. Shang E, Geiger N, Sturm JW, Post S. Pump-assisted enteral nutrition can prevent aspiration in bedridden percutaneous endoscopic gastrostomy patients. JPEN J Parenter Enteral Nutr 2004;28:180-3.

11. Niv E, Fireman Z, Vaisman N. Post-pyloric feeding. World J Gastroenterol 2009;15:1281-8.

12. Toh Yoon EW, Yoneda K, Nishihara K. Semi-solid feeds may reduce the risk of aspiration pneumonia and shorten postoperative length of stay after percutaneous endoscopic gastrostomy (PEG). Endosc Int Open 2016;4: E1247-51.

13. Muramatsu H, Okamoto T, Kubo T, Matsuki M, Iwata S, Fujiwara A, et al. Differences in the incidence of postoperative pneumonia after percutaneous endoscopic gastrostomy between liquid and semi-solid nutrient administration. Eur J Clin Nutr 2019;73:250-7. 